\title{
„Nie trzeba było domu palić, tylko Żydów wyprowadzić i pozabijać".
}

\author{
Postscriptum do tekstu Jerzego Mazurka i Aliny Skibińskiej \\ „Barwy Białe” w drodze na pomoc walczacej Warszawie: \\ zbrodnie AK na Żydach
}

Partyzanci pukali do drzwi - trzeba było wziąć łopatę i iść do lasu zakopywać ciała „pobitych Żydów”. Tak w Kaczkach, Mostkach, Stawku Starym wspomina się dziś Żydów, którzy ukrywali się dużą grupą w siekierzyńskich lasach jeszcze w sierpniu $1944 \mathrm{r}$.

„Żydy były pobite w Zabitym Lesie” - została też pamięć miejsca, ale nie udało nam się tam trafić, mimo wskazań miejscowych. Lato było wyjątkowo deszczowe i tamte, zawsze bagniste tereny, tak podmokły, że nawet samochodem z wysokim podwoziem nie dawało się przejechać. Wskazania też nie były nazbyt precyzyjne, powycinano całe połacie starych lasów, wyrosły nowe, więc polana, na której dokonano zbrodni, może okazać się porośnięta drzewami. Ale jeszcze długo po wojnie, gdy się wracało stamtąd z grzybami czy jagodami, to się mówiło „byłem w Zabitym”.

Zbrodni dokonał 17 sierpnia 1944 r. oddział „Barwy Białe”, które wchodził w skład 2. Dywizji Piechoty AK. Wyprowadzili Żydów na polanę i wszystkich rozstrzelali. Opis zbrodni na podstawie powojennego procesu i innych źródeł przedstawili Jerzy Mazurek i Alina Skibińska. Przepytywano świadków, których partyzanci wyciągali nocą do kopania grobu. Próbowaliśmy ich odszukać.

Wszyscy oni rzeczywiście mieszkali wtedy w okolicy. Nikt z nich nie żyje. W Kaczce, małej osadzie na skraju lasu, nawet niezaznaczonej na mapie - to z niej było najbliżej do miejsca zbrodni i stąd wyrywano w nocy ze snu młodych ludzi do wykopania zbiorowej mogiły - jest kilka zadbanych domów letniskowych. Pozostała tylko jedna osoba pamiętająca tamte czasy - Regina Babiarz, która była wtedy dziewiętnastoletnią dziewczyną i mieszkała w pobliskich Mostkach. Pytamy ją o świadków tamtego zdarzenia według nazwisk znanych nam $\mathrm{z}$ akt procesowych: Jeden po wojnie się powiesił, inni - kolejno umarli, pięć lat temu, dwa lata temu, ostatni zmarł dwa miesiące przed naszym przyjazdem.

Mówi nam: „Żydów pobili, nie wiem za co. W Skarżysku było dużo Żydów, było getto, oni pouciekali i się tu oparli. Tam Żydy były mieszane, nie tylko ze Skar- 
żyska. Najpierw ich obrabowały, bo miały złoto, a potem zabili. Oni mieli złoto, bo za to się żywili, dawali obrączki, a ludzie dawali im chleb. Do mojej teściowej przychodzili. Ona piekła chleb, wydawała go partyzantom i Żydom. Żydzi płacili, partyzanci - nie, bo nie mieli. Jak pobili Żydów, to kopali ludzie ze wsi”.

- Czy wiadomo było od razu, kto ich zamordował? - pytamy.

- Czy partyzantka, czy Niemcy, to nie wiem. Wiem tyle, że pobite było ze 20 Żydów.

- Wszyscy wiedzieli?

- No pewno, że wiedzieli.

- I co mówili?

- Nic o Żydach nie mówili, bo każdy się bał, żeby przeżyć.

- Żałowali zamordowanych?

- Żydów to nie żałowali, partyzantów tak, to żałowali.

Czytamy jej fragmenty zeznań jej ojca. Bolesław Bukowski był w czasie wojny sołtysem w Mostkach, sporej wsi, której Kaczki podlegały administracyjnie. „Zamordowanych zostało około pięćdziesięciu osób. Jak słyszałem, zostali oni rozstrzelani przez polską partyzantkę i tam prawdopodobnie zostali zakopani. Po wypadku tym słyszałem, że ubrania z nich zostały ściągnięte i były palone na miejscu, z powodu, że w ubraniach spodziewano się zaszytych drogocennych rzeczy, jak obrączki, i inne”.

Regina Babiarz: Polacy zabiły. No tak. Niemcy nie wiedziały, że Żydy są tam zabite. Słyszałam, że Żydzi mieli pozaszywane złoto.

W zeznaniach, które jej czytamy, pojawia się nazwisko Jana Tuśno z Kaczek, który był wyznaczony przez partyzantów do kopania mogiły.

Regina Babiarz: Tuśno przyszedł raz do mojego ojca i przyprowadził Żyda, który wyszedł z lasu za jedzeniem, a on go złapał. Widziałam to. Żyd był średniego wieku, miał zawiązaną ze słomy pętlę. Mój ojciec na to: „Ja nie chcę mieć nic wspólnego ani z Żydami, ani z tobą i nie chcę go bić. Masz tam Niemców - bo dalej stali Niemcy - to do nich idź”. Niemcy mówili, że dostanie się nagrodę. Spojrzeli, że Żyd, zabili i kazali mu rów wykopać. To był stary człowiek, ten Tuśno, połakomił się na nagrodę, a ta nagroda była taka, że mu grób kazali kopać. Że mu się tak chciało, kilka kilometrów, kawał drogi, na postronku człowieka ciągnąć. Jak tam poszłam popatrzeć z koleżankami, to Żyd już był zakopany”.

Regina Babiarz opowiada też, że jej ojciec pomógł Żydówce z dzieckiem. „U Hermanów na Szelejtowie, na drugiej ulicy była przechowywana Żydówka, którą mój ojciec tam przekazał”. Odnajdujemy w Mostkach-Szelejtowie córkę tego Maksymiliana Hermana, który ją miał przechować. Stanowczo zaprzecza. Jej ojciec żadnej Żydówki nie przechowywał. Wspomina o innej zbrodni w okolicy: „Żydzi byli za kopalnią, kopali kamień dla Niemców, bo to były kamieniołomy. Trochę się ukrywało i własne Polaki ich wybiły, tak słyszałam”.

Dla niej jest oczywiste, że Żydzi stanowili w czasie wojny zagrożenie. „Kiedyś widziałam dwóch zarośniętych, a potem na grzybach ktoś z sąsiadów ich spotkał, był cały w strachu, mówił: «Uciekłem, bo by mnie zabili w tym lesie»”. 
Niewiele więcej udało nam się dowiedzieć.

Szwagierce Reginy, Mieczysławie Babiarz z Suchedniowa, której mąż, mieszkaniec Kaczek, też kopał, przeczytaliśmy jego zeznania: „[Partyzanci] kazali mi zabrać łopatę i udać się z ww. i jednym partyzantem do lasu, co ja uczyniłem, gdy doszliśmy do miejsca, spotkaliśmy duży stos trupów nagich, nakrytych gałęziami [...]. Wykopaliśmy dół głębokości powyżej $1 \mathrm{~m}$, do którego pościągaliśmy trupów, których było około 50, między któremi były i kobiety. [...] Według mego uznania i opowieści ludzi, to mieli być Żydzi, którzy uciekli z getta ze Skarżyska Kam.”. Mieczysława Babiarz przypomina sobie, że mąż po wojnie był wzywany przez UB. „Partyzanci przyszli do niego, żeby zakopał, i na tym się skończyło” - mówi.

Władysław Sukniewicz (ur. 1931), który mieszka przy lesie za Kaczką, rozmawiał z nami przez płot, niechętnie. Opowiadał, że jego ojciec był u „Szarego” partyzantem.

- A Żydzi w tej okolicy ukrywali się? - pytamy.

- Podobno były pobite.

- Przez partyzantkę?

- To było kupę lat temu. Musiało być, że Niemce. W tę stronę, kawał dalej na Siekierno, były łąki, Żydzi mieli szałasy. Wybili ich. A te nasze partyzanty od „Szarego” musieli wykopać dół. Zginęło Żydostwo do kupy, słychać było strzały - tu tu tu tu. I potem, jak dobijali - bach, bach, bach”.

Jedziemy szukać innego grobu. W czerwcu 1944 r. dowódca oddziału „Barwy Białe” por. Kazimierz Olchowik „Zawisza” kazał rozstrzelać lekarza ze swego oddziału, podporucznika Wojska Polskiego o pseudonimie „Miś”, kiedy dowiedział się, że jest on Żydem. W procesie powojennym zeznawał Bolesław Kłobuc z gajówki koło wsi Lisów, który znalazł świeżo wykopany grób i dowiedział się na wsi, że grupa od „Zawiszy” zabiła swojego lekarza - Żyda. Mówił: „To była sprawa głośna we wsi”.

Nikt z tych mieszkańców dziś nie żyje. Rozmawialiśmy z synem Bolesława, Adamem Kłobucem. „Ojciec nie informował mnie, kto jest zabity, ale mówił, że zlikwidowali człowieka, mogiłę pokazywał, teraz się nie da odnaleźć, bo zapadła się potem ta ziemia, tam, gdzie grób, i zarósł las”. Opowiedział nam jeszcze o innej zbrodni w okolicy. „To było w Opatowie, po likwidacji getta. Młoda Żydówka ukrywała się przy rynku i ktoś ją sprzedał. Człowiek, który należał do AK, wyprowadził ją na cmentarz. Mój kolega Tadek Lewicki, on mi to opowiadał, poszedł za nimi. Jak to młody człowiek, chciał zobaczyć seks na żywo. A ten AK-owiec wyciągnął rewolwer i koło cmentarza wojennego strzelił tej młodej kobiecie w głowę. Nie powiem, kto to był, bo nazwisko znam z drugich ust, ale jak ten morderca był potem odznaczany, czułem awersję”. 
Jedziemy do Goździelina, gdzie członkowie sekcji specjalnej Referatu II AK w Podobwodzie Ćmielów, którzy potem przystapili do oddziału „Barwy Białe”, zamordowali siedmioro Żydów: trzech mężczyzn, dwie kobiety, dwoje dzieci: 6- i 12-letnie. Partyzanci spalili dom Marii Czuby, która przechowywała tych Żydów. Tak wynika z akt procesowych przedstawionych w tekście Mazurka i Skibińskiej.

Chociaż miejscowość jest spora, gdy chodziliśmy od domu do domu, udało nam się odnaleźć tylko trzy osoby, które mieszkały tu w czasie wojny, same kobiety.

Teodozja Cielebąg: „Nikt nie wiedział tego, że w dołach na górce są Żydzi. To się w nocy stało, a gdy rano już przyjechali Niemcy, to było wszystko dopalone. Potem to wszyscy wiedzieli, że u Czubiny, co wołali na nią Królica, spalili dom za Żydy”. Czuba była z domu Król, stąd przezwisko.

Amelia Wodecka (ur. 1924): „Dlaczego ich pozabijały, nie wiadomo, ktoś przyskarżył. Przyszli partyzanci i zamiast wyprowadzić i pozabijać na dworze, to pozabijali w chałupie. Kobiecina mogła wziąć tylko łóżko i pierzynę, co nie wyniosła, to się spaliło, jak podpalili chałupę. Płakała ta biedna kobieta, że została bez domu. Rano poleciałyśmy zaraz zobaczyć i tam leżały kupeczki Żydów. Sześć kupek było tych Żydów, co były spalone”. Jeszcze raz, przed pożegnaniem, rozmówczyni powtarza, że przecież nie trzeba było domu palić, tylko „wyprowadzić i pozabijać”. Niemców wspomina dobrze, niepytana, kilka razy powtarza, że „Niemcy to były takie porządne ludzie”.

Ostatnia rozmowa, z sąsiadką, znowu przez płot: „Miałam wtedy 10 lat. Biegaliśmy patrzeć. Ta starsza kobieta powynosiła wszystko z domu przed spaleniem, pamiętam, jak stały garnki”.

\title{
Słowa kluczowe
}

Pamięć Zagłady, stosunki polsko-żydowskie, badania terenowe

\begin{abstract}
The author visited the villages and towns where the murders of Jews hiding in the Kielce region after the liquidation of the ghettos took place (the acts were described in Jerzy Mazurek and Alina Skibińska's text published in this volume). Only a small number of inhabitants, who were there during the war, remains, but the memory of the murdered Jews is still present. Both the memory of those killed by the passing Home Army detachment (and who were buried by the locals who were ordered to do so) and the memory of those denounced by the locals, killed on the spot or escorted to a German police station. Memory does not always entail compassion. The article proves that field research, even one conducted so many years after the Holocaust, can introduce additional knowledge into historical research.
\end{abstract}

\section{Key words}

Holocaust memory, Polish-Jewish relations, field research 